\title{
Gamtos paveldo objektų būklès vertinimo metodologija
}

\section{Ligita Braškytė,}

\section{Regina Prapiestienè}

Vilniaus universitetas, M. K. Čiurlionio g. 27, 03101 Vilnius El.paštas: ligita.braskyte@gf.stud.vu.lt; regina.prapiestiene@gf.vu.lt
Braškytė L., Prapiestienė R. Gamtos paveldo objektų būklès vertinimo metodologija. Geologija. Geografija. 2018. T. 4(3). ISSN 2351-7549.

Straipsnyje analizuojamos gamtos paveldo objektų būklès vertinimo metodologinès prielaidos ir pateikiama gamtos paveldo objektų būklès vertinimo metodologija. Pirmiausia analizuota gamtos paveldo objekto sąvoka, gamtos paveldo objektų apsaugos teisinio reglamentavimo pagrindai bei atlikta valstybès saugomų gamtos paveldo objektų statistinė analizė. Atlikus analizę ịvardyti gamtos paveldo objektų būklę lemiantys tiesioginiai ir netiesioginiai veiksniai, objektu atsparumas fiziniam poveikiui. Remiantis surinktais duomenimis, sudaryta valstybės saugomu gamtos paveldo objektų būklès vertinimo metodika, kuri apima fizinès objekto būklès pokyčio ir objektui nustatytos buferinès apsaugos zonos būklès pokyčio ịvertinimus. Šiame straipsnyje pateikta būklès vertinimo metodika gali būti reikšminga renkant duomenis apie atskirų gamtos paveldo objektų būklę, identifikuojant gamtos paveldo objektų būklès blogèjimo priežastis ir formuojant prioritetines gamtotvarkos kryptis.

Raktažodžiai: gamtos paveldo objektas, paveldo objekto būklè, gamtos vertybès, lemiantys veiksniai, vertinimo metodika

\section{IVADAS}

XIX a. pr. vokiečiu geografas A. Humboltas pirmą kartą istorijoje pavartojo „monuments de la nature" - gamtos paminklo sąvoką (Humboldt, 1819; Conwentz, 1909). To meto geografijoje gamtos paminklais buvo traktuojami ịvairūs gyvosios ir negyvosios gamtos objektai: medžiai, kalvos, retos augalų ir gyvūnų rūšys ar net išlikusios natūralių dirvožemių teritorijos (Conwentz, 1909). Vis dèlto ši sąvoka nebuvo plačiai vartojama, todèl ilgainiui buvo užmiršta. Tačiau XX a. vid., po II pasaulinio karo, daug gamtinių teritorijų ir kultūros paveldo objektų buvo stipriai pažeisti (Hussein, 2016), todèl Jungtinių Tautų švietimo, mokslo ir kultūros organizacija (UNESCO) patyrè didžiuli ekonomini ir aplinkosaugini spaudimą iš valstybių narių, kad būtų imtasi atitinkamų priemonių paveldui išsaugoti. $1972 \mathrm{~m}$. buvo pri- imta Pasaulio paveldo konvencija, kurioje reglamentuojama ne tik kultūros, bet ir gamtos paveldo objektų apsauga bei jų valdymas (Konvencija, 1972; Labadi, 2014).

Lietuva konvenciją ratifikavo $1992 \mathrm{~m}$., po nepriklausomybės atkūrimo (Pasaulio kultūros..., 2006), tačiau gamtos objektų išsaugojimu susirūpinta gerokai anksčiau. $1921 \mathrm{~m}$. gamtininkas T. Ivanauskas analizavo, kokie gamtos objektai galètų būti laikomi gamtos paminklais, ir teigè, kad siekiant išsaugoti šiuos objektus būtina steigti organizaciją (Ivanauskas, 1921). T. Ivanauskas siekè, kad vertingiausiems gamtos objektams, tuo metu - gamtos paminklams, būtų suteiktas teisinis apsaugos statusas (Ivanauskas, 1921). Siekiant išsaugoti vertingiausius gamtinio kraštovaizdžio objektus, tarpukaryje buvo kuriami ir vis peržiūrimi gamtos paminklų nuostatai, tačiau gamtos objektus oficialiai paskelbti saugomais sutrukdè Lietuvos okupacija 
ir II pasaulinis karas (Jankevičius, Stasinas, 2000). Didelę reikšmę gamtos objektų teisinei apsaugai turejjo 1959 m. priimtas Lietuvos SSR gamtos apsaugos istatymas, kuriame reglamentuota gamtos paminklų apsauga. Istatymas draudè bet kokią veiklą, galinčią pakenkti gamtos objektams (Ragulskytè-Markoviené, 2005). Po įstatymo prièmimo, 1960 m., saugomais paskelbti pirmieji gamtos objektai, atitinkantys dabartinę gamtos paveldo objekto sampratą. Tai buvo pirmasis oficialus valstybės saugomų gamtos objektų sąrašas, kuriame objektai ịvardyti kaip gamtos paminklai (Mikalauskas, 2013). 1990 m. iš viso gamtos paminklais jau buvo paskelbta per 700 objektų (Dèl respublikinès..., 1990). 1993 m. priimtame Lietuvos Respublikos saugomų teritorijų įstatyme (toliau - Saugomų teritorijų ịstatymas), pirmą kartą Lietuvos gamtos apsaugą reglamentuojančiuose teisès aktuose paminèta frazè "gamtos paveldas“, o $2001 \mathrm{~m}$. instatymo redakcijoje ittvirtinama kaip sąvoka (Saugomų teritorijų..., 1993; 2001). Prieš ịteisinant sąvoką "gamtos paveldas", 1999 m. paskelbtas valstybès saugomų gamtinių kraštovaizdžio objektų sąrašas (Dèl valstybès saugomų..., 1999). 2003 m. šis sąrašas paskelbtas negaliojančiu, tačiau vietoj jo aplinkos ministras A. Kundrotas paskelbia įsakymą, kuriuo patvirtinamas pirmasis gamtos paveldo objektų sąrašas. Naujasis sąrašas apėmé 1999 m. saugomais paskelbtus vertingiausius gamtinio kraštovaizdžio objektus bei buvo papildytas naujais gamtos paveldo objektais. Objektų sąrašas iki šiol yra nuolat pildomas ir atnaujinamas (Dèl valstybės saugomų..., 2003).

Šiuo metu pagrindiniai dokumentai, reglamentuojantys gamtos paveldo objektų apsaugą, tvarkymą, naudojimą yra Saugomų teritorijų istatymas, Gamtos paveldo objektų nuostatai bei Gamtos paveldo objektų vertinimo ir reikšmingumo nustatymo kriterijų aprašas, tačiau nè viename iš šių teisès aktų nèra reglamentuotos gamtos paveldo objektų būklès vertinimo metodikos. Gamtos paveldo objektai, priklausomai nuo ju rūšies, gali būti itin jautrūs aplinkos poveikiui, o juos pažeidus būklès grąžinti $\mathfrak{i}$ ankstesnę padètị faktiškai neįmanoma, todèl siekiant igyvendinti pagrindinị Gamtos paveldo objektų nuostatuose pateiktą tikslą - išsaugoti vertingiausius gamtinio kraštovaizdžio objektus, labai svarbu turèti aiškią gamtos paveldo būklès vertinimo metodiką. Metodika padètų laiku pastebèti paveldo objektų būklès blogejjimo požymius, taip išvengtume visiško vertybių sunykimo. Todèl pagrindinis šio straipsnio tikslas - pateikti preliminarią gamtos paveldo objektų būklès vertinimo metodiką, paremtą statistinių duomenų analizès rezultatais ir sudarytą atsižvelgiant $\mathfrak{i}$ gamtos paveldo objektų būklę lemiančias priežastis.

\section{GAMTOS PAVELDO OBJEKTO SAMPRATA}

Siekiant sudaryti gamtos paveldo objektų būklès vertinimo metodiką, svarbu įvardyti, kas yra laikoma gamtos paveldu, gamtos paveldo objektu. Atsižvelgiant it tai, kad gamtos paveldo objektai yra saugomos teritorijos arba sudetiné saugomu teritorijų sistemos dalis, gamtos paveldo objekto sąvoka pateikiama pagrindiniame saugomu teritorijų sistemą, jos apsaugą, tvarkymą, veiklą jose ir kontrolę reglamentuojančiame teisès akte - Saugomų teritorijų istatyme (Saugomų teritorijų..., 2001).

Nuo tada, kai 1993 m. priimta pirmoji Saugomų teritorijų ístatymo redakcija, buvo pabrèžiama, kad saugomose teritorijose yra svarbi kompleksinè saugomų teritorijų apsauga, todèl gamtos ir (ar) kultūros paveldo vertybių išsaugojimas buvo viena iš saugomų teritorijų apsaugos prioritetinių sričių (Saugomų teritorijų..., 1993). Kompleksinis požiūris ị saugomas teritorijas įsitvirtino ir išliko iki šių dienų, tačiau, 1994 m. prièmus Nekilnojamųjų kultūros vertybių apsaugos istatymą bei kitus su saugomomis teritorijomis susijusius įstatymus, buvo būtina tam tikras Saugomų teritorijų įstatyme esančias sąvokas išgryninti arba atitinkamai integruoti naujas. $2001 \mathrm{~m}$. patvirtintoje Saugomų teritorijų i̇statymo redakcijoje įrašoma sąvoka „paveldo objektai“, pakeičianti saugomų kraštovaizdžio objektų (gamtos ir kultūros) sąvoką. Naujas apibrèžimas yra daug artimesnis kultūros paveldo apsaugos srityje nuo seno taikomai kultūros paveldo objekto sąvokai.

Paveldo objektai suskirstyti $\mathfrak{i}$ gamtos ir kultūros paveldo objektus, kurie gali būti saugomi atskiri arba sudaryti tankias grupes (Saugomu teritorijų..., 2001). 10-ame isstatymo straipsnyje detalizuojama, kad gamtos paveldo objektai yra saugomi gamtinio kraštovaizdžio objektai (Saugomų teritorijų..., 2001).

Labai svarbu suprasti, kad „gamtos paveldo objektas" nèra tik sąvoka, tai vienas iš saugomų 
teritorijų apsaugos statusų kaip ir nacionalinis parkas, regioninis parkas, draustinis, rezervatas ar kitos saugomos teritorijos. Gamtos paveldo objekto kaip saugomos teritorijos statusas itvirtintas paveldo objektų skelbimo saugomais tiksluose. Svarbiausi du tikslai: „išsaugoti gamtos ir kultūros paveldo objektus; išsaugoti kraštovaizdžio ir biologinę ìvairovę" (Saugomų teritorijų..., 2001). Šie tikslai parodo, kad kaip ir kitose saugomose teritorijose siekiant išsaugoti gamtos paveldo objektą labai svarbi kompleksinè teritorijos apsauga, kuri apima ne tik pati gamtini objektą, bet ir ji supanti kraštovaizdi bei toje teritorijoje esančią biologinę ịvairovę.

Gamtos paveldo objekto sąvoka apima platų spektrą gamtinio kraštovaizdžio objektų ir kompleksų, todèl Saugomų teritorijų isstatyme pateikta sąvoka "gamtos vertybès“. Ši sąvoka parodo, kokie gamtiniai objektai laikomi gamtos vertybėmis, kurioms suteikiamas specialus apsaugos statusas - gamtos paveldo objektas. Gamtos vertybès - tai ịvairūs gamtos objektai ir jų kompleksai, kurie vertingi moksline, ekologine, pažinimo prasme; yra reikšmingi kraštovaizdžiui ir biologinei ìvairovei išsaugoti; nuolatos ar periodiškai pasireiškiantys biotinès ar abiotinès gamtos reiškiniai bei procesai, kurie suteikia teritorijai vertę (Saugomų teritorijų..., 2001). Taigi, gamtos paveldo objektai - tai gamtos vertybès, kurios gali būti saugomos (1) kaip pavieniai objektai, pavyzdžiui, ozas, Barzdos kalnas - geomorfologinis gamtos paveldo objektas; (2) kaip kompleksai dèl tam tikros teritorijos vertès, pavyzdžiui, Vilkaičiu geomorfologiniame draustinyje (Dèl naujų valstybės..., 2018).

Ivairiuose užsienio autorių moksliniuose darbuose ar gamtos paveldo apsaugos strateginiuose dokumentuose gamtos paveldo objektai dažniausiai traktuojami ne kaip objektai, bet kaip plotinę išraišką turintys gamtinio kraštovaizdžio kompleksai, pasižymintys išskirtine moksline, estetine, biologine, ekologine, aplinkosaugine, geologine ar kita verte. Tai atskleidžia ir tarptautiniuose moksliniuose darbuose vartojama terminologija, ypač sąvoka nature heritage (Ontario..., 2010; Environmental..., 2011; Dorfman, 2012). Lietuvoje šią sąvoką atitiktų "gamtos paveldas“. Gamtos paveldas apima ne tik vertingiausius gamtinio kraštovaizdžio kompleksus, bet ir pavienes gamtos vertybes, kurios nesudaro kompleksų, tačiau dèl išskirtinès vertès yra paskelbtos saugomais gamtos paveldo objektais.
Kalbant apie tarptautinio lygmens dokumentus, sutartis ir konvencijas, kuriose reglamentuojama gamtos paveldo apsauga, reikia paminèti, kad pati svarbiausia yra Pasaulio kultūros ir gamtos paveldo apsaugos konvencija. Lietuvos Respublika minètąją konvenciją ratifikavo 1992 metais. Konvencijos 2 straipsnyje apibrèžiama, kad gamtos paveldu gali būti: „gamtos savybès, kurias sudaro fizinès ir biologinès struktūros ar tokių struktūrų grupès“; „geologinès ir fiziografinès struktūros ir tiksliai apibrèžtos teritorijos, kurios yra nykstančių gyvūnų ir augalų rūšių buveinès“; „gamtos vietovès arba tiksliai apibrèžtos teritorijos, turinčios išskirtinę visuotinę vertę mokslo, išsaugojimo ar gamtos grožio požiūriu“ (Pasaulio kultūros..., 2017, 2 str.).

Tarptautineje konvencijoje pateikta gamtos paveldo sąvoka ir nacionalinio lygmens teisès akte (Saugomų teritorijų įstatyme) įvardytos gamtos paveldo objekto ir gamtos vertybių sąvokos iš esmès yra tapačios. Vis dèlto svarbu pabrèžti, kad visos konvenciją ratifikavusios šalys saugo savo valstybės išskirtinius arba būdingus vertingiausius gamtinio kraštovaizdžio kompleksus ir pavienius gamtos objektus, todèl pasaulyje iki šiol vis dar nèra vieningos nuomonès ir susitarimo, kas iš tiesų yra gamtos paveldas (Lowenthal, 2006). Nors vartojama terminologija iš esmès gali skirtis, tačiau kontekstas išlieka vienodas.

Lietuvoje gamtos paveldas yra tai, kas vertinga, o gamtos paveldo objektai - kas saugoma plačiaja prasme, gali būti suprantami kaip pavieniai gamtos paveldo objektai, kuriems suteiktas saugomo gamtos paveldo objekto statusas, arba kaip saugomi gamtos vertybių kompleksai, kurie apima plotines, gyvosios ir negyvosios gamtos vertybes. Ši samprata yra labai plati ir apima beveik visą saugomų teritorijų sistemą, todèl šiame tyrime apsiribota valstybės saugomų gamtos paveldo objektu analize, kurios tikslas - pateikti Lietuvoje praktiškai naudojamą gamtos paveldo objektu būklès vertinimo metodiką.

\section{GAMTOS PAVELDO OBJEKTU APSAUGOS IR STEBĖSENOS REGLAMENTAVIMAS}

Pagrindinis teisès aktas, reglamentuojantis gamtos paveldo objektų apsaugą Lietuvoje, - Saugomų teritorijų isstatymas. Saugomų teritorijų ìstatymo 11 straipsnyje nurodomi tikslūs gamtos paveldo 
objektų teritorijose galiojantys veiklos reglamentai. Pagal 11 straipsnio 3 papunktí, visu gamtos paveldo objektų rūšių teritorijose yra neleidžiami šie veiksmai: naikinti ar kitaip žaloti objektus bei jų vertinguosius požymius; ịvairiais būdais gadinti žemès paviršių, pavyzdžiui, kasti ar arti, taip pat keisti riedulių pradinę vietą ar padètị, išskyrus tuos atvejus, kai šie darbai būtini siekiant objektą eksponuoti, tvarkyti ar naudoti; statyti bet kokio pobūdžio pastatus, išskyrus tuos, kurie susiję su objektų priežiūra ar reikalingi objektų eksponavimui (Saugomų teritorijų..., 2001).

Saugomų teritorijų istatymas taip pat numato, kad aplink gamtos paveldo objektus gali būti išskiriama buferinès apsaugos zona, kurią sudaro fizinès ir vizualinès apsaugos pozoniai (Saugomu teritorijų..., 2001). Vadovaujantis Saugomų teritorijų isstatymu, fizinès apsaugos pozonyje, be jau minètu veiklų, neleistina: laikyti bet kokias pavojingas sprogias, degias ar chemines medžiagas; keisti vandens lygi ir (ar) statyti bet kokius statinius, susijusius su minèta veikla; keisti upiu ir šaltinių vagų fizinius parametrus. Vizualinès apsaugos pozonyje neleistini darbai, kurie gali sumažinti paveldo apžvelgiamumą. Taip pat Saugomų teritorijų ístatymo 11 straipsnio 4 papunktyje nurodyta, kad gamtos paveldo objektų teritorijose ir $5 \mathrm{~km}$ spinduliu nuo jų neleistina auginti, dauginti pakeistų savybių organizmų ar augalų bei jų sèklų (Saugomų teritorijų..., 2001).

Kitas svarbus gamtos paveldo objektų apsaugą reglamentuojantis poịstatyminis teisès aktas - Gamtos paveldo objektų nuostatai. Gamtos paveldo objektų nuostatuose ịvardijama, kad fizinès apsaugos pozoniuose taip pat neleistina: statyti palapines, kurti laužus, teršti aplinką, statyti transporto priemones ne tam skirtose vietose ir važinètis ne keliais (Dèl Gamtos paveldo nuostatų..., 2005). Taip pat yra patikslinama, kad botaninès ir zoologinès kategorijos gamtos paveldo objektu teritorijose ir apsaugos zonose neleistina bloginti buveinių sąlygų, o vizualinès apsaugos pozonyje "gali būti ribojamas teritorijos užstatymo aukštingumas bei intensyvumas" (Dèl Gamtos paveldo nuostatų..., 2005). Nors Saugomu teritorijų įstatymas ir Gamtos paveldo objektų nuostatai reglamentuoja gamtos paveldo objektų apsaugą, tačiau nèra teisès akto, kuriame būtų itteisinta gamtos paveldo objektų būklès stebèsenai igyvendinti skirta metodika, kuria remiantis būtų galima konstatuoti gamtos paveldo objektų fizinès būklès blogèjimą arba gerèjimą.

Saugomų teritorijų ístatymo 27 straipsnio 5 papunktyje pažymima, kad kraštovaizdžio ir gamtos vertybių būklès stebèseną koordinuoja ir būklès vertinimą organizuoja Valstybinè saugomų teritorijų tarnyba prie Aplinkos ministerijos, o jai pavaldžios saugomų teritorijų direkcijos „atlieka gamtos vertybių stebėseną ir kaupia informaciją apie gamtos paveldo objektus (Saugomų teritorijų..., 2001). Stebèsena privalo būti atliekama vadovaujantis Aplinkos monitoringo įstatymo nustatyta tvarka (Saugomų teritorijų, 2001; Aplinkos monitoringo..., 2006). Nors gamtos paveldo objektų būklès stebèsena yra privaloma, tačiau teisès aktuose nenustatyta, kokia vertinimo metodika turi būti naudojama. Vis dèlto Saugomu teritorijų valstybès kadastre atnaujinamos objektų nuotraukos rodo, kad neoficialiai stebèsena ir objektų fotofiksacija yra vykdoma, tačiau būklès fiksavimo aktai nèra pildomi. Tokia stebèsena nenuosekli, neleidžia objektyviai ịvertinti būklès pokyčio, prognozuoti tolimesnès objektų būklès ar teisingai sudèlioti gamtos paveldo objektu tvarkymo prioritetus.

Reikètų pabrèžti, kad jau 2005 m. kultūros ministro įsakymu Nr. IV-199 patvirtintos Kultūros paveldo objekto būklès tikrinimo taisyklès (Dèl Kultūros paveldo objekto būklès..., 2005), kai gamtos paveldo objektų būklès vertinimo metodikos vis dar nèra. Kita vertus, nepaisant patvirtintų taisyklių, kultūros paveldo būklès stebėsena iki šiol vyksta vangiai, kadangi šis procesas reikalauja didelių žmogiškųjų, materialinių ir laiko išteklių (Braškytè, Prapiestienè, 2018). Saugomose teritorijose kultūros paveldo objektų gali būti keli šimtai. Vertinant būklę visi be išimties objektai privalo būti nufotografuoti ịvairiais rakursais, surašyti būklès ịvertinimo aktai (Dèl Kultūros paveldo objekto būklès..., 2005).

Atsižvelgiant ị tai, kad atskirose savivaldybèse ar saugomose teritorijose kultūros paveldo objektu gali būti net keli šimtai, o gamtos paveldo objektu atskirose savivaldybėse ar saugomose teritorijose yra ne daugiau kaip 42 (būtent tiek objektų šiuo metu yra Dzūkijos nacionaliniame parke) (Saugomu teritoriju valstybès kadastras, 2018), gamtos paveldo objektų būklès stebèseną būtų galima atlikti kur kas paprasčiau ir efektyviau nei kultūros paveldo objektų būklès stebėseną. 


\section{GAMTOS PAVELDO OBJEKTỤ BŪKLĖS VERTINIMO METODOLOGINÉS PRIELAIDOS}

Siekiant išsaugoti gamtos paveldo objektus ateities kartoms ir sustabdyti gamtos paveldo objektu nykimą, itin svarbu turèti aiškią gamtos paveldo objekto būklès vertinimo metodiką, kuri ne tik egzistuotų teoriškai, bet ir galètų būti naudojama praktiškai. Siekiant parengti vertinimo metodiką labai svarbu ivertinti su tyrimo objektu susijusius statistinius duomenis, o gautas išvadas panaudoti kuriant metodiką.

Naujausi duomenys atskleidžia, kad Lietuvoje savivaldybių saugomais paskelbta 217 gamtos paveldo objektų (Saugomų teritorijų valstybès kadastras, 2018). I valstybès saugomų gamtos paveldo objektų sąrašą atlikus statistinę analizę įrašyti 684 gamtos paveldo objektai, iš jų 159 yra pripažinti itin vertingais, todèl Vyriausybès nutarimu paskelbti gamtos paminklais (Dèl Naujų valstybès..., 2018; Dèl gamtos paminklų..., 2000). Net 357 objektai, kurie sudaro 52 \% visų gamtos paveldo objektų, yra saugomose teritorijose, iš jų net $86 \%$ yra kompleksinèse saugomose teritorijose - nacionaliniuose $(25,5 \%)$ ir regioniniuose parkuose $(60,5 \%)$. Iš valstybès saugomų gamtos paveldo objektų $26 \%$ sudaro geologiniai objektai, $6,3 \%$ - hidrogeologiniai, 5,4 \% - geomorfologiniai, 3,4 \% - hidrografiniai, 58,8 \% - botaniniai ir $0,1 \%$ - zoologiniai.

Pirmieji dabartinę gamtos paveldo objekto sampratą atitinkantys gamtos paveldo objektai paskelbti valstybės saugomais $1999 \mathrm{~m}$. (žr. ịvadą), nuo tada vidutiniškai kas metus sąrašas yra atnaujinamas (Dèl valstybės saugomų..., 1999). Nuo 1999 m. iki 2018 m. i valstybès saugomuc gamtos paveldo objektų sąrašą iš viso buvo ịrašytas net 261 gamtos paveldo objektas. $2006 \mathrm{~m}$. patvirtinus Savivaldybių draustinių steigimo ir savivaldybių gamtos paveldo objektų skelbimo tvarkos aprašą bei $2009 \mathrm{~m}$. patvirtinus Gamtos paveldo objektų vertinimo ir reikšmingumo nustatymo kriterijų aprašą (Savivaldybių draustinių..., 2006; Gamtos paveldo objektų vertinimo..., 2006), objektus iš sąrašo pradèta išbraukti, jei pastarieji sunykdavo arba neatitinka valstybès saugomiems objektams keliamų reikalavimų. Jie buvo perkeliami $\mathfrak{i}$ savivaldybių gamtos paveldo objektų sąrašus.
Per pastaruosius devyniolika metų ị savivaldybių gamtos paveldo objektų sąrašus perkelta 11 objektu, 34 objektai buvo prarasti negrižtamai ir apskritai išbraukti, o i sąrašą įrašyti net 257 nauji objektai. Objektų skaičiaus kaita (1999-2018 m.) pateikta 1 paveiksle. Gamtos paveldo objektų sunykimas bėgant laikui yra neišvengiamas, vidutiniškai per metus prarandami 3-4 gamtos paveldo objektai, tai rodo atlikta statistinè analizé, tačiau svarbu paminèti, kad kiekvienais metais daug naujų gamtos objektų yra paskelbiami valstybès saugomais. Statistinè analizè atskleidè, kad daugiau kaip $50 \%$ visų sunykusių objektų buvo kompleksinèse saugomose teritorijose, o $90 \%$ miškų ūkio bei žemès ūkio paskirties kraštovaizdžio tvarkymo zonose. 32 iš 34 sunykusių gamtos paveldo objektų buvo botaniniai, kiti du - geologiniai. Sunykę objektai buvo ganètinai sunkiai prieinamose ir ne kiekvienam turistui žinomose vietose, todèl didelè tikimybè, kad jiems neigiamos įtakos galèjo turèti būtent žemès ar miškų ūkio veikla. Žemès ūkio teritorijose ar miškuose esančių gamtos paveldo objektų būklès prastèjimo pirmuosius ženklus specialistams ir saugomose teritorijose besilankantiems turistams, kurie galètų pranešti apie objekto būklę, sudètingiau pastebèti, todèl tikètina, kad tokiais atvejais objekto sunykimo ženklai pamatomi per vèlai arba tik tada, kai objektas jau būna visiškai sunykęs.

Vis dèlto pasitaiko itin įžūlių atvejų, kai gamtos paveldo objektai dèl asmeninio intereso piktavališkai naikinami visuomenès. Vienas iš tokių atvejų yra sunaikintas botaninis gamtos paveldo objektas - Kretuonių pirmasis ąžuolas, jis buvo išbrauktas iš valstybès saugomu gamtos paveldo objektų sąrašo. Aukštaitijos nacionaliniame parke buvęs gamtos paveldo objektas tam tikrą laiką buvo žalojamas cheminèmis medžiagomis, o po kurio laiko stipriai apgenètas paliekant vien kamieną be šaku (Saugomu teritoriju valstybès..., 2018).

Gamtos paveldo objektų būklès prastèjimo priežastys gali būti skirtingos, todèl ir būklès stebèsenos metodika turi būti kuo ịvairesnè, apimti kaip įmanoma daugiau kriterijų, juolab kad gamtos paveldo objektų būklè priklauso ir nuo gamtos paveldo objekto rūšies. Rengiant vertinimo metodiką, pirmiausia ịvertintas gamtos paveldo objektu atsparumas fiziniam poveikiui ir nustatytos pagrindinès priežastys, lemiančios objektų 


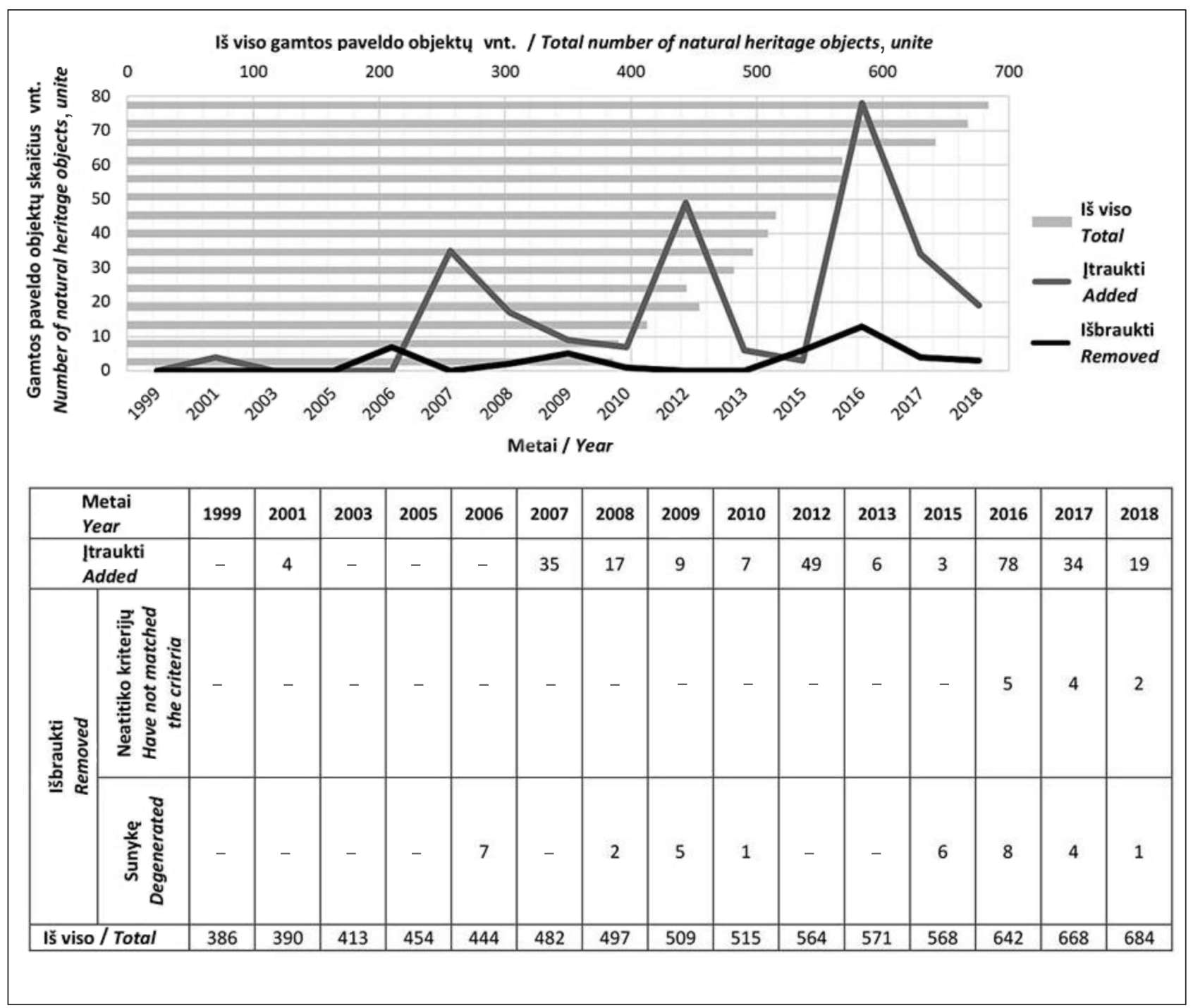

1 pav. Gamtos paveldo objektų skaičiaus kaita 1999-2018 m. (duomenys: Dèl valstybès saugomų..., 1999; Dèl Lietuvos..., 2001; Dèl valstybės..., 2003, 2005; Dėl Aplinkos..., 2006; Dėl Naujų..., 2007, 2012, 2013; Dèl Naujų..., 2008, 2009, 2010, 2015, 2016; Dèl Naujų..., 2017, 2018)

Fig. 1. Changes in the number of nature heritage objects from 1999 to 2018 (source: Dél valstybes saugomu..., 1999; Dèl Lietuvos..., 2001; Dèl valstybès..., 2003, 2005; Dèl Aplinkos..., 2006; Dèl Naujų..., 2007, 2012, 2013; Dèl Nauju..., 2008, 2009, 2010, 2015, 2016; Dél Naujų..., 2017, 2018)

būklę. Schematiškai būklès prastèjimą lemiantys veiksniai vaizduojami 2 paveiksle.

Skirtingų rūšių gamtos paveldo objektai yra nevienodai atsparūs fiziniam poveikiui, kurị sukelia tiesioginiai ir (arba) netiesioginiai veiksniai. Mažiausia fiziniam poveikiui atsparūs zoologiniai, botaniniai, o atspariausi - hidrografiniai ir geomorfologiniai gamtos paveldo objektai. Jų atsparumą fiziniam poveikiui parodo pilkos spalvos rodyklès ir kryptis (2 pav.). Vienos rūšies gamtos paveldo objektai apima labai skirtingas saugomas gamtos vertybes, kurios tarpusavyje taip pat skiriasi atsparumu fiziniam poveikiui. Atitinkamai gamtos paveldo objektai pažymèti indeksais: A - atsparūs, Ma - mažiau atsparūs fiziniam poveikiui.

Fizinis poveikis objektams priklauso nuo netiesioginių arba tiesioginių veiksnių (2 pav.). Netiesioginiai veiksniai - tai veikla, kuri pirmiausia pažeidžia ne patị objektą, o objekto aplinką, dèl kurios pasikeitimo prasteja ir bendra objekto būklè. Prie netiesioginių veiksnių priskiriama ir žmogiškujų, materialinių išteklių stygius ir kt. Tokio pobūdžio veiksniai taip pat neturi tiesioginès 


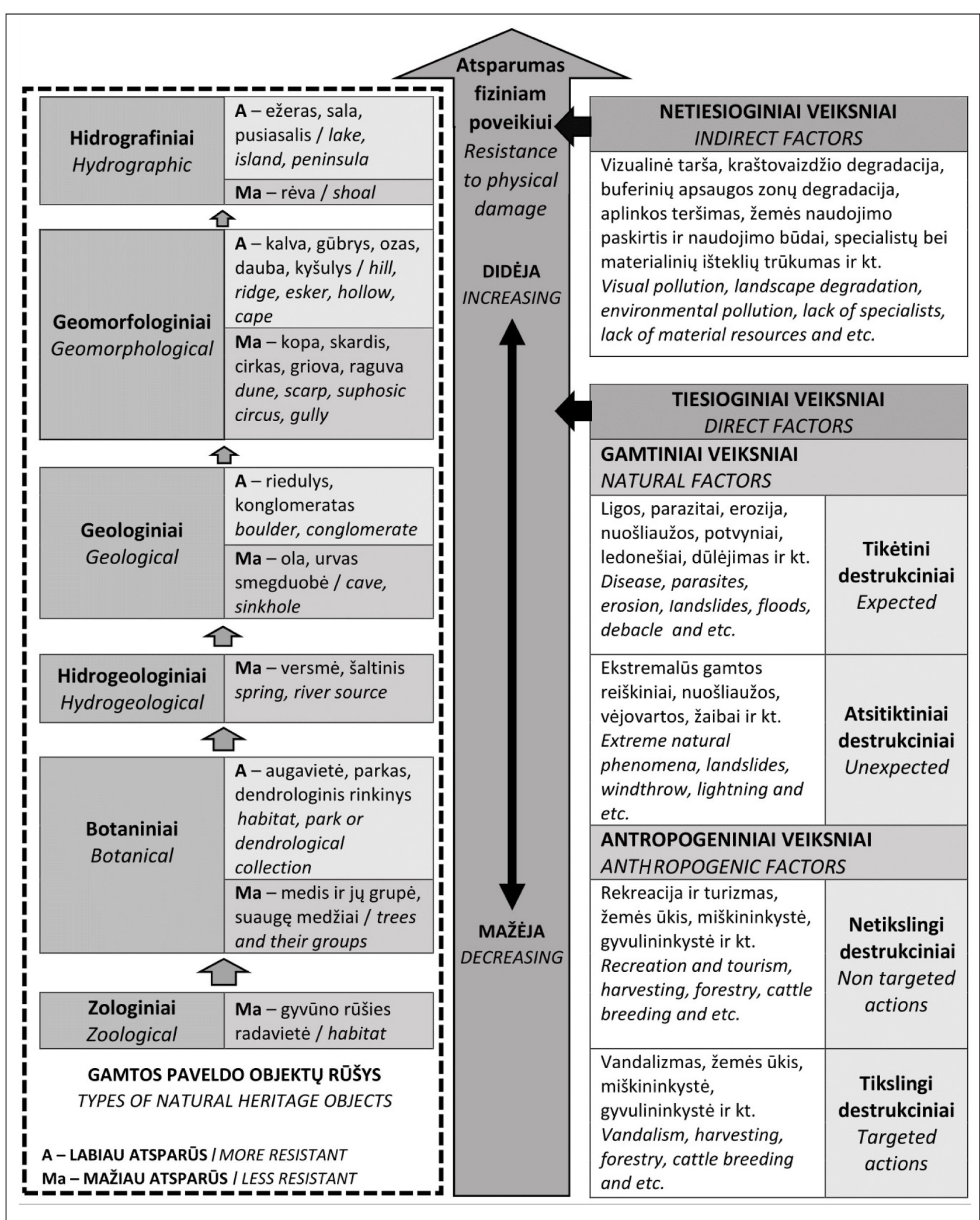

2 pav. Gamtos paveldo objektų būklę lemiančios priežastys

Fig. 2. Factors affecting nature heritage

ittakos objektų fizinei būklei, tačiau jie itin svarbūs, kadangi pastebejus pirmuosius gamtos paveldo objekto būklès prastejimo požymius reikia nedel- siant imtis priemonių, kad būtų sumažintos arba visiškai pašalintos priežastys. Už gamtos paveldo objektų tvarkymą atsakingi asmenys turi išmanyti 
savo darbą, būti tos srities specialistai. Netinkamu botaninių gamtos paminklų tvarkymo pavyzdžiu galètų būti senų drevètų medžių "gelbejjimas" užmūrijant jų dreves, neva taip sumažinamas tolimesnis puvimo procesas, arba drevių apkalimas bronzinèmis plokštèmis, kurioms oksiduojantis išsiskiria nuodinga medžiaga - patina (Stelmužès ąžuolas..., 2010).

Tokiais būdais buvo tvarkomi net seniausias botaninis gamtos paveldo objektas - Stelmužès ąžuolas, esantis Zarasų rajone (3 pav.), ir Zervynų ąžuolas (4 pav.) Dzūkijos nacionaliniame parke.

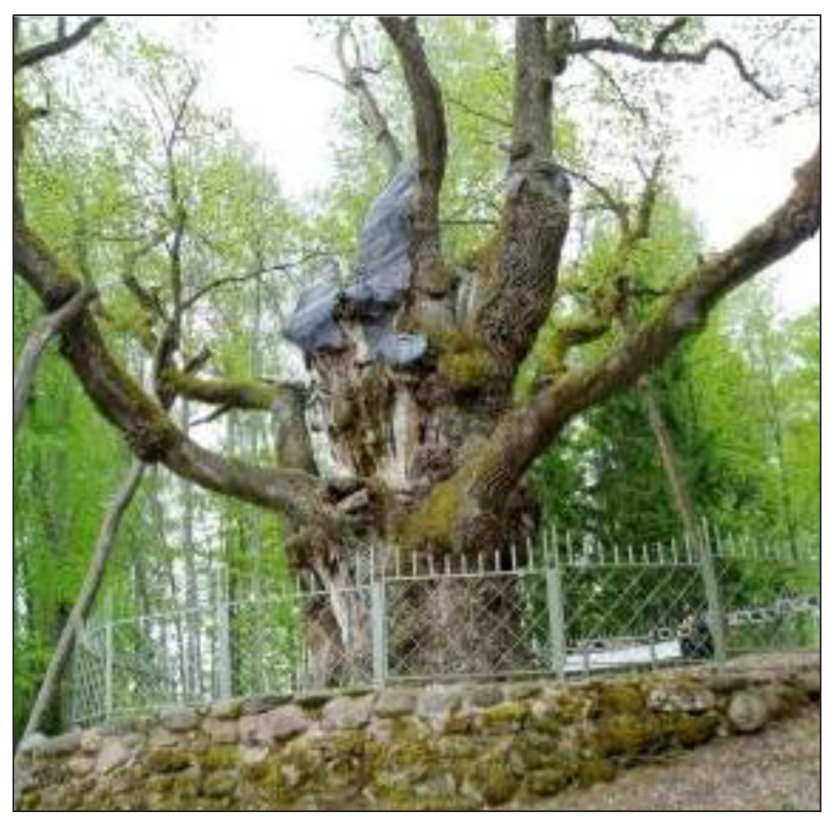

3 pav. Stelmužès ąžuolas 2010 m. (šaltinis: www.vstt.lt) Fig. 3. Stelmužé oak in 2010 (source: www.vstt.lt)

Išskiriami ir tiesiogiai veiksniai, darantys neigiamą poveikị fizinei gamtos paveldo objektų būklei. Jie skirstomi $\mathfrak{i}$ gamtinius ir antropogeninius veiksnius. Gamtiniai veiksniai dar grupuojami $\mathfrak{i}$ tikettinus destrukcinius ir atsitiktinius destrukcinius. Tikètinais veiksniais laikomi ìvairūs cheminiai, fiziniai procesai ir gamtos reiškiniai, kurie objektus daugiau ar mažiau veikia nuolatos arba tų veiksnių atsiradimas gali būti prognozuojamas. Atsitiktiniais laikomi tie veiksniai, kuriu prognozuoti neįmanoma. Tai daugiausia stichinès nelaimès ir ịvairūs gamtos reiškiniai. Pabrèžtina, kad tam tikrais atvejais atsitiktiniai destrukciniai veiksniai gali tapti tiketinais destrukciniais veiksniais ir atvirkščiai. Gamtos paveldo objektus veikia ir antropogeniniai veiksniai, kurie apima bet kokią

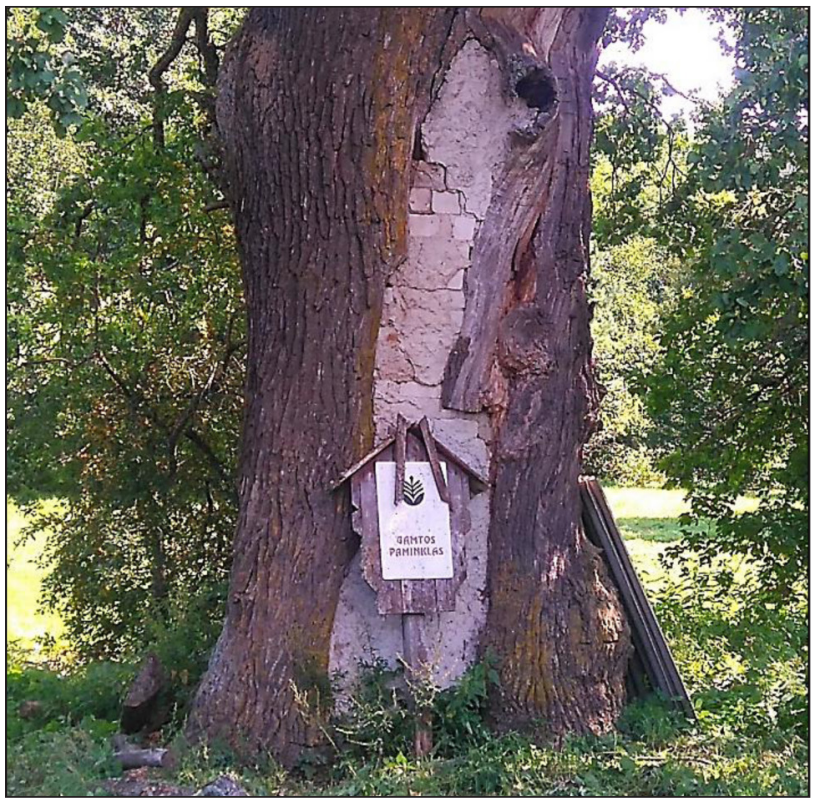

4 pav. Zervynų ąžuolas Dzūkijos nacionaliniame parke 2018 m. L. Braškytès nuotr.

Fig. 4. Zervynos oak in Dzükija national park in 2018 (photo of the author)

žmogaus veiklą, kuri turi neigiamos įtakos gamtos paveldo objektų būklei. Antropogeniniai veiksniai skirstomi i netikslingus destrukcinius - tai žmogaus veikla, kuri kenkia gamtos paveldo objekto būklei, tačiau yra atliekama neturint blogų ketinimų arba trūkstant žinių. Tikslingi destrukciniai veiksniai - tai piktavališka veikla, siekiant pakenkti gamtos paveldo objektui.

Bendrai kalbant apie gamtos paveldo objektų būklę lemiančias priežastis reikètų paminèti, kad 2 pav. pavaizduotoje schemoje ivvardytos priežastys yra tik pavyzdžiai, kadangi priežasčių gali būti ir daugiau. Schemoje matyti, kad daugiausia gamtos paveldo objektų būklei ịtakos turi tiesioginiai tikslingi antropogeniniai veiksniai, o mažiausia - netiesioginiai veiksniai. Objektų rūšių išdėstymas rodyklès kryptimi nusako paveldo rūšies atsparumą fiziniam poveikiui. Kuo atsparumas mažesnis, tuo objektas lengviau paveikiamas tiesioginių ir netiesioginių veiksnių.

\section{GAMTOS PAVELDO OBJEKTŲ BŪKLĖS VERTINIMO METODIKA}

Atlikus gamtos paveldo objektų statistinių duomenų analizę ir įvertinus gamtos paveldo objektų būklę lemiančius veiksnius, gamtos paveldo objektų rūšių atsparumą fiziniam poveikiui bei su 
gamtos paveldo objektų būkle susijusias tendencijas, toliau sudaryta būklès stebèsenos metodika. Ši metodika tinkama vertinti visas gamtos paveldo objektų rūšis, nepaisant jų fizinių charakteristikų ir skirtumų.

Metodiką sudaro du vertinamieji kriterijai:

a) gamtos paveldo objekto fizinès būklès pokytis;

b) gamtos paveldo objekto teritorijai nustatytos buferinès apsaugos zonos būklès pokytis.

Gamtos paveldo objekto fizinès būklès pokytis yra svarbiausias kriterijus, todèl jis bus nustatomas penkiabale vertinimo skale. Pabrěžiama, kad skaičius vertinimo skalèje objekto būklès neparodo. Skaičius atskleidžia nuokrypi nuo stabilios gamtos paveldo objekto būklès, kuri vertinimo skalëje žymima skaičiumi 3. Skaičius, didesnis už 3, parodo būklès gerẻjimą. Šiuo atveju būklès gerèjimas gali reikšti, kad prieš tai objektas buvo prastos būklès, tačiau dabar yra tvarkomas - šalinamos priežastys. Skaičiai, mažesni už 3, parodo, kad objekto būklè blogejja ir objektui gresia sunykimas (1 lentelè).
Antrasis kriterijus - gamtos paveldo objekto teritorijai nustatytos buferinès apsaugos zonos būklès pokytis. Paprastai buferinès apsaugos zona pažymima teritorijų planavimo dokumentuose arba specialiose schemose. Vis delto gamtos paveldo objektams, kurie yra valstybiniuose rezervatuose, nacionalinių ir regioninių parkų konservacinio funkcinio prioriteto zonose (rezervatuose ir draustiniuose), buferinès apsaugos zonos nenustatomos (Saugomų teritorijų..., 2001). Saugomiems taškiniams gamtos paveldo objektams, pavyzdžiui, pavieniams medžiams, rieduliams, su objektu susijusi teritorija taip pat neišskiriama (Dèl Gamtos paveldo nuostatų..., 2005). Teritorijų planavimo dokumentuose šie objektai žymimi taškais, nepriklausomai, ar pastarieji patenka $\mathfrak{i}$ saugomą teritoriją, ar ne. Kai objektas neturi apibrèžtos teritorijos arba buferinès apsaugos zona objektui nenustatyta, privalo būti vertinama teritorija, kurios nuotolis nuo paveldo objekto atitinka gamtos paveldo objektų nuostatuose numatytų fizinès apsaugos pozonių nuotolius (Dèl Gamtos paveldo nuostatų..., 2005). Vertinant gamtos

\section{1 lentelè. Gamtos paveldo objektų fizinès būklès pokytis}

\section{Table 1. Changes in physical condition of nature heritage objects}

\begin{tabular}{c|c}
\hline $\begin{array}{c}\text { Gamtos paveldo objektų fizinès } \\
\text { būklès pokytis / Changes in physical } \\
\text { condition of nature heritage object }\end{array}$ & Paaiškinimas / Explanation \\
\hline $\begin{array}{c}5 \text { - būklè pagerejusi / physical condition } \\
\text { of the object has improved }\end{array}$ & $\begin{array}{c}\text { Pašalinti natūralią objektui būdingą fizinę išraišką menkinantys ele- } \\
\text { mentai / elements diminishing the natural physical expression character- } \\
\text { istic of the object are eliminated }\end{array}$
\end{tabular}

4 - būklè gerejja / physical condition of the object is improving

3 - būklè stabili / physical condition of the object is stable

2 - būkle blogeja / physical condition of
the object is deteriorating

1 - būklè pablogèjusi / physical condition of the object is deteriorate

0 - būklè kritiška / physical condition of the object is critical
Šalinami natūralią objektui būdingą fizinę išraišką menkinantys elementai / elements diminishing the natural physical expression characteristic of the object are being eliminating

Objektas geros būklès, natūraliai jam būdingos fizinès išraiškos nepakeitęs / the object is in good condition without physical alteration

Objektas iš dalies pakeitęs natūraliai jam būdingą fizinę išraišką, matyti būklę menkinantys elementai, tačiau objekto vertè nemažèja / the object has altered its natural physical expression, elements that diminish the state are visible, but the value of the object is not decreasing

Objektas stipriai pakeitęs natūraliai jam būdingą fizinę išraišką, pokyčiai itin ryškūs ir menkinantys objekto vertę / the object has strongly changed its natural physical expression, changes are very significant and diminishing the object's value

Objektas beveik visiškai praradęs natūraliai jam būdingą fizinę išraišką arba visiškai sunykęs, objektas praradęs vertę / the object has almost completely lost its natural physical expression or is completely destroyed, the object has lost its value 
2 lentelè. Gamtos paveldo objekto teritorijos ir jam nustatytos buferinès apsaugos zonos būklès pokytis Table 2. Changes in conditions of nature heritage object territory and its protection area

\section{Gamtos paveldo objekto teritorijos ir jam nustatytos buferinès apsau- gos zonos būklès pokytis / Changes in conditions of nature heritage object territory and its buffer zone}

5 - būklè gera /condition is good
Paaiškinimas / Explanation

Teritorija sutvarkyta, pašalinti objektą užgožiantys elementai, teritorijoje pašalinti vizualinès, fizinès, biologinès, antropogeninès ar kiti taršos šaltiniai ir jų padariniai / the environment is well-organized, elements blocking/overshadowing the object are eliminated, the sources of visual, physical, biological, anthropogenic or other pollution and their consequences are eliminated from the territory
4 - būklè gerejja / condition is improving
Teritorija pradèta tvarkyti, šalinami objektą užgožiantys elementai, teritorijoje šalinami vizualinès, fizinès, biologinès, antropogeninès ar kiti taršos šaltiniai ir ju padariniai / the environment has begun to be managed, the object is being unblocked, the sources of visual, physical, biological, anthropogenic or other pollution and their consequences are being eliminating from the territory
3 - būklè stabili / condition is stale

2 - būklè blogèja / condition is deteriorating
Teritorija pakankamai tvarkinga, objektą užgožiančių elementų nėra, teritorijoje nèra vizualinès, fizinès, biologinès, antropogeninès ar kitų taršos šaltinių ir jų sukeltų padarinių / the environment is tidy, no elements blocking/overshadowing the object, no visual, physical, biological, anthropogenic or other sources of pollution and their consequences in the territory

Teritorija mažai tvarkoma, objektas iš dalies užgožtas, teritorijoje galima matyti vizualinès, fizinès, biologinès, antropogeninès ir kitų taršos šaltinių ar jų sukeltu padarinių / the environment is poorly managed, the object is partially overshadowed, the sources of visual, physical, biological, anthropogenic or other pollution and their consequences can be seen in the territory

1 - būklè bloga / condition is bad
Teritorija netvarkoma, objektas užgožtas, teritorijoje daug vizualinès, fizinès, biologinès, antropogeninès ir kitų taršos šaltinių ar jų sukeltų padariniuc / the environment is not organized, the object is overshadowed, many visual, physical, biological, anthropogenic or other sources of pollution or their consequences in the territory paveldo objektų, esančių valstybiniuose rezervatuose arba rezervatuose, esančiuose nacionaliniuose ir regioniniuose parkuose, teritorijos būklès pokyti, pablogèjusi laikoma tik tais atvejais, kai tai lèmé antropogeniniai veiksniai (2 pav.).

Gamtos paveldo objekto teritorijos ir jam nustatytos buferinès apsaugos zonos būklès pokytis nustatomas penkiabale skale. Kaip ir vertinant pirmąji kriterijų - fizinę objekto būklę, skaičius vertinimo skalèje parodys nuokrypi nuo stabilios - estetinès paveldo objekto vertès, tinkamos apžiūrèti ir lankyti objektą. Skaičiai, didesni už 3, rodo, kad objektą supančios teritorijos būklè gerèja. Itvertinimai, mažesni už 3 , rodo teritorijos keitimąsi, degradaciją (2 lentelè).
Ši būklès vertinimo metodika gali padèti nustatyti esamą gamtos paveldo objektų situaciją, formuoti prioritetines gamtos tvarkymo kryptis, išsaugoti vertingiausius gamtinio kraštovaizdžio objektus, palaikyti ir gerinti kraštovaizdžio estetinę vertę.

\section{IŠVADOS}

1. Gamtinis kraštovaizdis apima: taškines ir plotines, gyvosios ir negyvosios gamtos vertybes, saugomas kaip pavieniai objektai, kuriems suteiktas saugomo gamtos paveldo objekto statusas, arba kaip gamtos vertybių kompleksai, kuriems atitinkamai suteikiamas draustinio, rezervato, nacionalinio, regioninio parko ar kitas statusas. 
2. Siekiant užtikrinti vertingiausių gamtinio kraštovaizdžio objektų - vertybių išsaugojimą, privalu periodiškai vykdyti gamtos paveldo objektų būklès stebèseną, atitinkamai prieš tai būtina parengti objektų būklès stebèsenos metodiką ir ją itteisinti. Metodika padètų ìvertinti gamtos paveldo objektų būklę, laiku pastebèti jos blogejjimo požymius ir išvengti spartaus vertybių nykimo.

3. Skirtingos gamtos paveldo objektų rūšys yra nevienodai atsparios jų būklę lemiantiems gamtiniams, antropogeniniams, tiesioginiams ir netiesioginiams veiksniams, todèl įvertinus objekto atsparumą fiziniam poveikiui stebèsena prioritetine tvarka turètų būti atliekama objektams, kurie pasižymi mažiausiu atsparumo fiziniam poveikiui.

4. Gamtos paveldo objektai yra neatsiejami nuo juos supančios aplinkos, todèl gamtos paveldo objektų būklès vertinimo metodika turi apimti dvi vertinimo dalis: gamtos paveldo objekto fizinés būklès pokytị ir gamtos paveldo objektui nustatytos buferinès apsaugos zonos būklès pokytị.

5. Gamtos paveldo objektų būklès vertinimo metodika gali būti reikšminga: renkant duomenis apie atskirų gamtos paveldo objektų būklę, formuojant prioritetines gamtos tvarkymo kryptis ir identifikuojant gamtos paveldo objektų būkles blogèjimo priežastis.

Gauta 20181108

Priimta 20181129

\section{NAUDOTA LITERATŪRA}

1. Braškytė L., Prapiestienè R. 2018. Kuršių nerijos nacionalinio parko paveldo būklès vertinimas. Geologija. Geografija. 4(1): 42-54.

2. Conwentz A. 1909. The Care of Natural Monuments with Spetial Reference to Great Britain and Germany. Cambridge: The University Press.

3. Dorfman E. 2012. Intangible Natural Heritage: New Perspectives on Natural Objects. New York: Routledge.

4. Environmental Resources Management Australia. 2011. Condition and integrity assessment of natural heritage places. Report prepared for the Australian Government Department of Sustainability, Environment, Water, Population and Communities on behalf of the State of the Environment 2011 Committee. Canberra: DSEWPaC.

5. Humboldt A. de. 1819. Voyage aux regions equinoxiales. Tome II. Paris, p. 59.
6. Hussein Moustafa L. 2016. Cultural heritage and preservation: lessons from World War II and the contemporary conflict in the Middle East. The American Archivist: Fall/Winter. 79(2): 320-338.

7. Ivanauskas T. 1921. Gamtos paminklai ir ju klausimas Lietuvoje. Kaunas: Lietuvos gamtos tyrimo stotis.

8. Jankevičius K, Stasinas J. 2000. Lietuvos aplinkosaugos raida. Vilnius: ABO.

9. Labadi S. 2014. UNESCO World Heritage Convention (1972). In: C. Smith (ed.). Encyclopedia of Global Archaeology. New York: Springer.

10. Lietuvos Respublikos kultūros vertybiu registras. 2018. https://kvr.kpd.lt/\#/static-heritage-search (žiūrèta 20170402 ).

11. Lietuvos Respublikos saugomu teritoriju istatymas. Žin., 1993, Nr. 63-1188; 2001, Nr. 108-3902.

12. Lietuvos Respublikos saugomu teritoriju valstybès kadastras. 2018. https://stk.am.lt (žiūrèta 201804 05).

13. Lietuvos TSR valstybinio gamtos apsaugos komiteto isakymas „Dèl respublikinès reikšmés valstybiniu geologiniu gamtos paminklu paskelbimo“. Žin., 1990, Nr. 22.

14. Lowenthal D. 2006. Natural and cultural heritage. International Journal of Heritage Studies. 11(1): 81-92.

15. LR aplinkos ministro isakymas „Dèl aplinkos ministro 2002 m. gruodžio 20 d. jsakymo Nr. 652 „Dèl valstybès saugomų gamtos paveldo objektų sąrašo patvirtinimo"pakeitimo“. Žin., 2006 Nr. 35-1259.

16. LR aplinkos ministro isakymas „Dèl gamtos paveldo objektu nuostatu patvirtinimo“. Žin., 2005, Nr. 582026.

17. LR aplinkos ministro įsakymas „Dèl gamtos paveldo objektų vertinimo ir reikšmingumo nustatymo kriterijų aprašo patvirtinimo“. Žin., 2009, Nr. 83-3476.

18. LR aplinkos ministro isakymas „Dèl Lietuvos Respublikos aplinkos ministro $1999 \mathrm{~m}$. lapkričio $3 \mathrm{~d}$. isakymo Nr. 345 „Dèl valstybès saugomy gamtiniu kraštovaizdžio objektu paskelbimo" pakeitimo ir papildymo“. Žin., 2001 Nr. 8-244.

19. LR aplinkos ministro isakymas „Dèl nauju valstybes saugomu gamtos paveldo objektu paskelbimo, ju ribu schemu patvirtinimo, sunykusiu valstybès saugomu gamtos paveldo objektu išbraukimo ir Lietuvos Respublikos aplinkos ministro $2002 \mathrm{~m}$. gruodžio $20 \mathrm{~d}$. isakymo Nr. 652 „Dél valstybés saugomu gamtos paveldo objektų sąrašo patvirtinimo" pakeitimo". TAR., 2017 Nr. 6605; TAR., 2018 Nr. 6126.

20. LR aplinkos ministro isakymas „Dél nauju valstybés saugomu gamtos paveldo objektu paskelbimo, ju ribu planu patvirtinimo ir aplinkos ministro $2002 \mathrm{~m}$. gruodžio 20 d. i̇sakymo Nr. 652 „Dél valstybés saugomu gamtos paveldo objektu sarašo patvirtinimo" pakeitimo“. Žin., 2007 Nr. 75-2992; Žin., 2012 Nr. 683480; Žin., 2013 Nr. 115-5780. 
21. LR aplinkos ministro ịsakymas „Dèl nauju valstybès saugomu gamtos paveldo objektu paskelbimo, ju ribu plany patvirtinimo, sunykusiu valstybés saugomy gamtos paveldo objektu išbraukimo ir aplinkos ministro 2002 m. gruodžio 20 d. įsakymo Nr. 652 „Dèl valstybès saugomu gamtos paveldo objektu sąrašo patvirtinimo" pakeitimo". Žin., 2008 Nr. 67-2539; Žin., 2009 Nr. 151-6815; Žin., 2010 Nr. 95-4984; Žin., 2015 Nr. 625; TAR., 2016 Nr. 2673.

22. LR aplinkos ministro isakymas „Dèl valstybès saugomu gamtiniu kraštovaizdžio objektu paskelbimo“. Žin., 1999, Nr. 95-2755.

23. LR aplinkos ministro issakymas „Dèl valstybès saugomu gamtos paveldo objektu sąrašo patvirtinimo“. Žin., 2003, Nr. 4-146.

24. LR aplinkos ministro isakymas „Dèl valstybès saugomu gamtos paveldo objektu sąrašo patvirtinimo pakeitimo“. Žin., 2005, Nr. 71-2566; Žin., 2007 Nr. 752992.

25. LR aplinkos monitoringo istatymas. Žin., 1997, Nr. 112-2824; 2006, Nr. 57-2025.

26. LR kultūros ministro ìsakymas „Dèl kultūros paveldo objekto būkles tikrinimo taisykliu patvirtinimo".Žin., 2005, Nr. 62-2213.

27. LR Vyriausybès nutarimas „Dél gamtos paminklu paskelbimo“. Žin., 2000, Nr. 24-621.

28. LR Vyriausybès nutarimas „Dél savivaldybiu draustiniu steigimo ir savivaldybiu gamtos paveldo objektu skelbimo tvarkos aprašo patvirtinimo". Žin., 2006, Nr. 9-335.

29. Mikalauskas G. 2013. Žvilgsnis ị saugomus gamtos geopaveldo objektus. Geologijos akiračiai. 1(73): 30-41.

30. Current and Projected Future Climatic Conditions for Ecoregions and Selected Natural Heritage Areas in Ontario. 2010. Ontario: Ontario Ministry of Natural Resources.

31. Pasaulio kultūros ir gamtos paveldo apsaugos konvencija (2017 m. patikslintas vertimas). TAR., 2017, Nr. 7165.

32. Pasaulio kultūros ir gamtos paveldo apsaugos konvencija. Žin., 2006 Nr. 73-2766.

33. Ragulskytè-Markovienè R. 2005. Aplinkos teisé: Lietuvos teisés derinimas su Europos Sajungos reikalavimais. Vilnius: Eugrimas.

34. Stelmužés ąžuolas - mokslininku akiratyje. 2010. http://www.vstt.lt/VI/article.php?article_id=784 (žiūrèta 201805 05).
Ligita Braškytė, Regina Prapiestienė

\section{THE METHODOLOGY FOR EVALUATION OF THE STATE OF NATURE HERITAGE OBJECTS}

Sum mary

The article analyzes the methodological assumptions for evaluation of nature heritage objects and provides a new methodology for research into nature heritage objects' physical condition. First of all, in order to create a comprehensive, theoretically and practically usable methodology, the problem of the concept of the object of nature heritage and the legal basis of nature heritage protection were analyzed.

The analysis revealed that the concept of nature heritage is defined very properly in the national legal acts, but so far there is no approved methodology in any law or subordinate legal act for research into nature heritage objects' physical condition. Considering the problems of nature heritage research field, the article presents methodological assumptions for the assessment of nature heritage objects' physical condition.

The assumptions show that every object has a level of physical resistance. This level depends on the type of the object, but every type of the object can be affected by direct and indirect factors that can be caused by humans or nature. All factors can influence physical condition and have a negative effect on the territory where the object is. Consequently, the methodology for research into nature heritage objects includes an assessment of changes in the physical condition of the nature heritage object and changes in conditions of the object's territory and its buffer zone.

The methodology is based on the principle of expert assessment, where the physical condition of each object is evaluated on a 1 to 5 scale and the territory of the object and its buffer zone is also evaluated on a 1 to 5 scale. The number does not indicate the condition of the object but only expresses the condition of the object's deviation from its stable state.

This type of methodology can be very effective in predicting future treats. Also, it can be significant from the theoretical aspect - collecting data about the nature heritage objects, and from the practical aspect - developing priority directions of nature management and identifying problematic areas of nature heritage objects.

Keywords: nature heritage object, condition of a heritage object, nature values, factors affecting nature heritage, evaluation methodics 